\title{
Pomalidomid w skojarzeniu z klarytromycyną i deksametazonem w podwójnie opornym szpiczaku plazmocytowym - opis przypadku i przegląd piśmiennictwa
}

\author{
Pomalidomide in combination with clarithromycin and \\ dexamethasone for double refractory plasma cell myeloma \\ - a case report and review of literature
}

\author{
Agnieszka Szeremet, Tomasz Wróbel \\ Klinika Hematologii, Nowotworów Krwi i Transplantacji Szpiku, \\ Samodzielny Publiczny Szpital Kliniczny, Uniwersytet Medyczny we Wrocławiu
}

\begin{abstract}
Streszczenie
Pomalidomid jest nowym lekiem immunomodulujacym stosowanym $w$ terapii szpiczaka plazmocytowego (PCM) w postaciach opornych i nawrotowych. Ponizej przedstawiono przypadek chorej na PCM opornej bortezomib i lenalidomid, leczonej pomalidomidem w skojarzeniu z klarytromycyna i deksametazonem.
\end{abstract}

Słowa kluczowe: oporny szpiczak plazmocytowy, pomalidomid

Hematologia 2016; 7, 3: 250-256

\begin{abstract}
Pomalidomide is a new immunomodulatory drug used for treatment of plasma cell myeloma (PCM). In this paper, we describe a case report of a woman with PCM who was double refractory to bortezomib and lenalidomide, and was subsequently treated with pomalidomide with clarithromycin and dexamethasone.
\end{abstract}

Key words: refractory plasma cell myeloma, pomalidomide

Hematologia 2016; 7, 3: 250-256

\section{Wprowadzenie}

Szpiczak plazmocytowy (PCM, plasma cell myeloma) stanowi $1 \%$ wszystkich nowotworów, w tym 10-15\% nowotworów hematologicznych. Wprowadzenie do terapii nowych grup leków, między innymi leków immunomodulujących (IMiD, immunomodulatory drugs), takich jak talidomid, lenalidomid, pomalidomid (POM, pomalidomide), oraz inhibitorów proteasomu (PI, proteasome inhibitors) - bortezomibu i karfilzomibu (CAR, carfilzomib), znacznie poprawiło rokowania u chorych na PCM. W praktyce klinicznej u chorych $Z$ nowo rozpoznanym PCM w pierwszej linii leczenia stosuje się schematy chemioterapii zawierające bortezomib. Lenalidomid jest lekiem często stosowanym u pacjentów opornych na PI i/lub z towarzyszącą polineuropatią. Ze względu na 
przewlekły i nawrotowy charakter PCM obecnie coraz większym wyzwaniem jest leczenie chorych opornych zarówno na PI, jak i IMiD (DRMM, double refractory multiple myeloma). Poniżej przedstawiono opis przypadku pacjentki z DRMM, która w czasie długoletniego okresu choroby nabyła lekooporności na standardowe leki stosowane w przebiegu PCM.

\section{Opis przypadku}

Kobieta w wieku 62 lat, $z$ rozpoznanym w 36. roku życia PCM klasy IgA typu kappa w stadium klinicznym IIIA według klasyfikacji Durie i Salmona, będąca pod opieką przyklinicznej poradni hematologicznej, została przyjęta do kliniki w czerwcu 2014 roku z powodu kolejnej progresji choroby.

W dotychczasowym leczeniu chora w latach 1989-1990 otrzymała 6 cykli VMBCP (winkrysytna, melfalan, karmustyna, cyklofosfamid, prednizon), a następnie przez 2 lata stosowano u niej monoterapię melfalanem. W maju 1992 roku pacjentka wyjechała do Włoch, gdzie ze względu na młody wiek poddano ją allogenicznemu przeszczepieniu krwiotwórczych komórek macierzystych (allo-HSCT, allogeneic hematopoietic stem cell transplantation) od brata. Po allo-HSCT uzyskano 15-letnią remisję choroby. W 2007 roku nastąpił nawrót PCM, zastosowano wówczas talidomid $z$ deksametazonem. Po 3 latach leczenia obserwowano wystąpienie polineuropatii czuciowej 3. stopnia, która była przyczyną zmiany terapii na schemat Rd (lenalidomid, deksametazon). Chora otrzymała 39 cykli Rd, a w profilaktyce leczenia zmian kostnych stosowano kwas zolendronowy.

Przed przyjęciem do szpitala u pacjentki występowały postępujące osłabienie, narastające bóle kostne, $z$ incydentem nagłego bólu w okolicy lędźwiowej kręgosłupa oraz żeber. W morfologii krwi obwodowej stwierdzono niedokrwistość normocytarną, normochromiczną 2. stopnia oraz małopłytkowość 2 . stopnia według Światowej Organizacji Zdrowia (WHO, World Health Organization). Wykluczono hemolizę, krwawienie $z$ przewodu pokarmowego, niedobór żelaza, kwasu foliowego i witaminy B12 jako przyczyny występującej niedokrwistości. W badaniach biochemicznych obserwowano wzrost stężenia kreatyniny do $2,6 \mathrm{mg} /$ /dl, obniżenie klirensu kreatyniny według wzoru Cockrofta-Gaulta do $18,7 \mathrm{ml} / \mathrm{min} / 1,73 \mathrm{~m}^{2}$, hiperkalcemię, hiperfosfatemię, hiperproteinemię wynoszącą $105 \mathrm{~g} / \mathrm{l}$, podwyższone do $25,9 \mathrm{mg} / 1$ stężenie $\beta_{2}$-mikroglobuliny, przyspieszony do $112 \mathrm{~mm} / \mathrm{h}$ odczyn opadania krwinek czerwonych, przy prawidłowych parametrach stanu zapalnego i krzepnięcia.
W badaniu immunofiksacji surowicy wykazano obecność białka monoklonalnego klasy IgA typu kappa we frakcji $\alpha_{2}$ globulin w stężeniu $58,9 \mathrm{~g} / \mathrm{l}$. Stężenie wolnych łańcuchów lekkich (FLC, free light chain) typu kappa wynosiło $751 \mathrm{mg} / \mathrm{l}$, a FLC typu lambda - 0,99 mg/l. Stosunek FLC kappa/ /lambda wyniósł 755. Rozpoznano progresję PCM według kryteriów Międzynarodowej Grupy Roboczej ds. Szpiczaka (IMWG, International Myeloma Working Group). W badaniu rezonansu magnetycznego (MRI, magnetic resonance imaging) kręgosłupa lędźwiowo-krzyżowego stwierdzono zmiany zwyrodnieniowe oraz dyskopatyczne $z$ obecnością wypuklin typu bulging disc na poziomach L3/L4, L4/ /L5 i L5/S1 uciskających worek oponowy, bez cech kompresyjnego złamania kręgów, nie uwidoczniono także ognisk osteolizy. Ze względu na ciężki stan pacjentki nie poszerzono wówczas diagnostyki o badanie MRI całego ciała, badania cytogenetyczne i trepanobiopsję.

Poza leczeniem objawowym zdecydowano o rozpoczęciu kolejnej chemioterapii (bortezomib, adriamycyna, deksametazon). Uzyskano zmniejszenie dolegliwości bólowych, poprawę parametrów funkcji nerek oraz stabilizację choroby. Kontynuację leczenia według schematu Vd (bortezomib, deksametazon) zaplanowano w trybie ambulatoryjnym. Pacjentka otrzymała 2 cykle Vd, po których obserwowano progresję choroby.

Od sierpnia 2014 roku rozpoczęto terapię za pomocą POM w połączeniu $z$ małymi dawkami deksametazonu (Pd), a częściową remisję choroby (PR, partial response) uzyskano po 2. cyklu leczenia. W kolejnych miesiącach stosowania Pd 2-krotnie wystąpiło zapalenie płuc 2 . stopnia według WHO, co skutkowało czasowym przerwaniem terapii. Następnie obserwowano progresję choroby. Od marca 2015 roku, w celu zwiększenia skuteczności leczenia, do schematu Pd dołączono klarytromycynę (ClaPd). Ze względu na niedokrwistość 3. stopnia oraz neutropenię 3 . stopnia według WHO pacjentka okresowo wymagała substytucji koncentratu krwinek czerwonych oraz stosowania czynnika pobudzającego wzrost kolonii granulocytów. Częściowa odpowiedź na leczenie według schematu ClaPd utrzymywała się przez 6 miesięcy. We wrześniu 2015 roku stwierdzono progresję choroby, miesiąc później pacjentka zmarła.

\section{Dyskusja}

Mimo postępu w terapii PCM ogromnym wyzwaniem pozostaje leczenie pacjentów w kolejnych nawrotach choroby, szczególnie w przypadku 
wystąpienia oporności na IMID i PI. Kumar i wsp. [1] przeprowadzili analizę przeżycia wolnego od zdarzeń (EFS, event-free survival) oraz przeżycia całkowitego (OS, overall survival) u 286 pacjentów z DRMM. W analizowanej grupie mediana EFS wynosiła 5 miesięcy, mediana OS -9 miesięcy, a jedynie $24 \%$ chorych osiągnęło co najmniej PR na kolejną linię leczenia. Powyższą analizę zaktualizowali w 2016 roku Usmani i wsp. [2], uwzględniając pacjentów z DRMM leczonych za pomocą CAR i POM. Badaniem objęto 662 chorych; mediana OS wyniosła 8 miesięcy.

$\mathrm{Na}$ wybór leczenia w grupie pacjentów z DRMM wpływają ich stan ogólny, obecność chorób wspólistniejących, skuteczność i tolerancja dotychczas stosowanego leczenia oraz dostęp do nowych leków. Pogorszenie funkcji nerek występuje u 25-50\% chorych na PCM - wiąże się nie tylko $z$ przebiegiem klinicznym nowotworu, ale także wynika ze współwystępowania uszkodzenia nerek w przebiegu częstych chorób wspólistniejących, takich jak nadciśnienie tętnicze i cukrzyca [3]. U pacjentów $z$ przewlekłą chorobą nerek wybór chemioterapii zależy od stopnia eliminacji leków przez nerki [4]. Kolejnym istotnym aspektem, który należy uwzględnić przy wyborze terapii u pacjentów z DRMM, jest obecność polineuropatii obwodowej. W 75\% przypadków wynika ona z toksyczności dotychczasowego leczenia, a szczególnie często jest obserwowana po talidomidzie i bortezomibie [5, 6]. W badaniach klinicznych z zastosowaniem CAR i POM nie obserwowano występowania polineuropatii obwodowej 3 . stopnia według WHO [7, 8]. U pacjentów z DRMM liczne, wcześniejsze linie leczenia istotnie wpływają na obniżoną rezerwę szpikową i większą tendencję do występowania pancytopenii. W wyborze kolejnej terapii trzeba wziąć pod uwage jej potencjalny potencjał mielosupresyjny.

W grupie pacjentów $z$ DRMM można zastosować między innymi POM, CAR, daratumumab i panobinostat. W badaniu FOCUS oceniano skuteczność CAR w porównaniu $z$ małymi dawkami kortykosteroidów (Ld) \pm cyklofosfamid (Cy) [9]. Mediany przeżycia wolnego od progresji (PFS, progression-free survival) i OS wynosily, odpowiednio, 3,7 w porównaniu z 3,3 miesiąca oraz 10,2 w porównaniu $z$ 10,0 miesięcy w grupach leczonych CAR w porównaniu $z$ leczonymi $\mathrm{Ld} \pm \mathrm{Cy}$. Należy podkreślić, że mediana wcześniejszych linii leczenia wynosiła 5 , a $68 \%$ chorych poddano wcześniej autologicznemu przeszczepieniu krwiotwórczych komórek macierzystych (auto-HSCT, autologous hematopoietic stem cell transplantation).
Obiecujące wyniki z zastosowaniem daratumumabu (przeciwciało monoklonalne anty-CD-38) obserwowano w grupie pacjentów $z$ DRMM w badaniu SIRIUS [10]. Mediany PFS i OS wynosity, odpowiednio, 3,7 i 17,5 miesiąca. Należy podkreślić, że w badanej grupie pacjentów mediana poprzedzających terapii wynosiła 5 , poza opornością na IMiD I i II generacji oraz PI I generacji, 63\% chorych wykazywało oporność na POM, a $45 \%$ na CAR.

Inhibitory deacetylazy histonowej, między innymi panobinostat i worinostat, należą do kolejnej grupy leków wykazujących aktywność u pacjentów z DRMM. Interesującą obserwację przedstawiono w badaniu VANTAGE-095, w którym u pacjentów $z$ DRMM zastosowano ponownie bortezomib w terapii skojarzonej $z$ worinostatem $i$ udowodniono ich synergistyczną aktywność wobec komórek PCM. Mediana PFS wynosiła 3,1 miesiąca, a mediana OS - 11,2 miesiąca. Jednak w badaniu PANORAMA2 wykazano jedynie minimalną korzyść $z$ zastosowania panobinostatu [11, 12].

Trwają badania kliniczne nad nowszymi inhibitorami proteasomu (iksazomib, marizomib, oprozomib), inhibitorami deacetylazy histonowej (rocilinostat) oraz przeciwciałem monoklonalnym (elotuzumab), które w przyszłości mogą stanowić kolejną opcję terapeutyczną $[11,13]$.

U pacjentów $z$ DRMM można także rozważyć zastosowanie schematu chemioterapii $\mathrm{D}(\mathrm{T})$ PACE (deksamsetazon \pm talidomid, cisplatyna, doksorubicyna, cyklofosfamid i etopozyd) [14]. W 2013 roku opublikowano wyniki retrospektywnej analizy służącej ocenie skuteczności D(T)PACE u 75 pacjentów z DRMM. Mediana PFS wynosiła 5,5 miesiąca, a mediana OS - 14 miesięcy. U 35 pacjentów leczenie to stanowiło terapię pomostową do auto-HSCT lub do badań klinicznych z zastosowaniem nowych leków. W tej grupie chorych uzyskano wydłużenie median PFS i OS, odpowiednio, do 13,4 i 20,5 miesiąca. Podczas stosowania D(T)PACE odnotowano dość dużą toksyczność, dlatego mediana zastosowanych cykli chemioterapii wyniosła 2, a $49 \%$ chorych zakończyło leczenie po 1 . cyklu. Retrospektywną ocenę przeprowadzono wśród chorych leczonych w latach 1999-2000, wówczas dysponowano ograniczonym dostępem do nowoczesnych terapii.

W badaniu Ludwiga i wsp. [15] oceniono skuteczność terapii według schematu BBD (bendamustyna, bortezomib, deksametaz). W podgrupie pacjentów z DRMM leczonych wcześniej bortezomibem i lenalidomidem mediana PFS wynosiła 7,1 miesiąca, a mediana OS $-17,4$ miesięcy. Terapia 
była dobrze tolerowana, a leukopenię, małopłytkowość, infekcje i polineuropatię w co najmniej 3. stopniu według WHO obserwowano, odpowiednio, u $18,7 \%, 38 \%, 23 \%$ i $6 \%$ chorych.

W prospektywnym badaniu Sellnera i wsp. [16] oceniono rolę ponownej auto-HSCT z kondycjonowaniem melfalanem. Całkowity odsetek odpowiedzi na leczenie (ORR, overall response rate) wyniósł $80,4 \% . \mathrm{W}+100$. dobie po procedurze auto-HSCT remisję obserwowano u $36 \%$ pacjentów, a śmiertelność wynosiła 3\%. Mediany PFS i OS wynosily, odpowiednio, 15,2 i 42,3 miesiąca. Wyniki te są optymistyczne, ponieważ dotyczą grupy pacjentów cechujących się korzystnymi czynnikami rokowniczymi (niska wartość w Międzynarodowym Systemie Prognostycznym (ISS, International Staging System), długie PFS po pierwszym auto-HSCT). Tym niemniej na uwage zasługuje analiza w podgrupie pacjentów charakteryzujących się niekorzystnymi czynnikami rokowniczymi, u których mediany PFS i OS wynosiły, odpowiednio, 7,2 i 11,6 miesiąca. Obecnie nie dysponujemy randomizowanymi badaniami, w których oceniono by rolę ratunkowej auto-HSCT u pacjentów $z$ DRMM.

Procedura allo-HSCT u pacjentów z PCM nie jest postępowaniem standardowym. Według rejestru EBMT (European Bone Marrow Transplantation) w latach 1983-1993 w Europie wykonano 334 przeszczepienia szpiku w PCM. Odnotowano wysoki, 54-procentowy odsetek trwałych remisji po 6 miesiącach i 60-procentowy po 2 latach. Prawdopodobieństwo OS po 2 , 4 i 6 latach wynosiło, odpowiednio, $40 \%, 32 \%$, 28\%. Co interesujące, 6 pacjentów $z$ opisywanej grupy przeżyło więcej niż 10 lat, w tym opisywana chora. Obserwowano wysoki odsetek śmiertelności po 6 miesiącach $38 \%$, a po 2 latach $-21 \%$, co przemawia na korzyść stosowania bezpieczniejszych procedur u chorych na PCM [17]. Według aktualnych wytycznych allo-HSCT powinno się stosować w szczególnych przypadkach i w ramach kontrolowanych prób klinicznych [18].

Opcją terapeutyczną w grupie pacjentów z DRMM jest zastosowanie między innymi POM - leku immunomodulującego o silnym działaniu przeciwproliferacyjnym i proapoptycznym. Do immunologicznych efektów POM należą zwiększone aktywacja i proliferacja komórek immunologicznych, w tym limfocytów T, komórek naturalnej cytotoksyczności (NK, natural killer) i dendrytycznych, hamowanie proliferacji i funkcji regulatorowych limfocytów T oraz zwiększenie produkcji cytokin immunostymulujących (interferon $\gamma[\mathrm{IFN} \gamma]$ i interleukina 2 [IL-2]). Aktywność przeciwszpiczakowa POM wiąże się $z$ modulacją ekspresji genów w klonalnych plazmocytach, tj. zwiększeniem ekspresji genów supresorowych nowotworów, na przykład $p 21^{W A} F 1$, oraz zmniejszeniem ekspresji onkogenów, na przykład IRF [19-22]. Pomalidomid indukuje także apoptozę zmienionych nowotworowo plazmocytów, aktywując kaspazę 8, oraz hamuje resorpcję tkanki kostnej zależną od osteoklastów poprzez obniżenie aktywacji szklaku czynnika jądrowego $\kappa \mathrm{B}(\mathrm{NF} \kappa \mathrm{B}$, nuclear factor $\kappa B)[23,24]$.

Dotychczas opublikowano wyniki badań $z$ zastosowaniem POM w monoterapii oraz $\mathrm{w}$ terapii skojarzonej z deksametazonem, Cy, CAR, bortezomibem, klarytromycyną oraz liposomalną doksorubicyną. Skuteczność leczenia za pomocą POM w połączeniu z małymi dawkami deksametazonu $(\mathrm{Pd})$, w porównaniu $z$ dużymi dawkami deksametazonu (HiDEX, high-dose dexamethasone) stosowanymi $\mathrm{w}$ monoterapii, oceniono $\mathrm{w}$ wielośrodkowym, randomizowanym badaniu klinicznym III fazy (MM-003), które przeprowadzono u 455 pacjentów z DRMM [25]. Mediany OS oraz PFS w grupie leczonej według schematu Pd wyniosły, odpowiednio, 11,9 i 3,8 miesiąca w porównaniu z 7,8 i 1,9 miesiąca w grupie leczonej za pomocą HiDEX. Najczęstszymi hematologicznymi zdarzeniami niepożądanymi 3.-4. stopnia według WHO w grupie leczonej Pd oraz w grupie leczonej HiDEX były neutropenia (48\% v. 16\%), niedokrwistość (33\% v. 37\%) i małopłytkowość (22\% v. 26\%). Analogicznie najczęstszymi niehematologicznymi zdarzeniami niepożądanymi 3.-4. stopnia według WHO były, odpowiednio, zapalenie płuc (13\% v. 8\%), bóle kości $(7 \%$ v. $5 \%)$ i zmęczenie (5\% v. 6\%).

Szansę na poprawę wyników leczenia można uzyskać, dodając Cla do schematu terapii $\mathrm{Pd}$ (ClaPd) [26, 27]. Badaniem objęto 114 osób; mediany OS i PFS wynosity, odpowiednio, 19 i 8,6 miesiąca i były dłuższe niż w badaniu MM-003. Całkowity odsetek odpowiedzi wśród pacjentów z DRMM uzyskało $56 \%$, w tym u $5 \%$ były to odpowiedzi całkowite ( $\mathrm{CR}$, complete response), u $12 \%$ - bardzo dobre odpowiedzi częściowe (VGPR. very good partial response), a u 39\% - PR. Występowanie zdarzeń niepożądanych 3.-4. stopnia według WHO odnotowano u porównywalnego odsetka chorych, jak w badaniu MM-003, tym niemniej istotnie zmniejszyła się liczba infekcji. W publikacjach dotyczących skuteczności schematu ClaPd nie badano dotychczas mechanizmu działania i wpływu Cla na POM. Zagadnienie to analizowano w poprzednich badaniach, w których zastosowano talidomid i lenalidomid w połączeniu z Cla [28-30]. 
Klarytromycyna jest antybiotykiem makrolidowym i wykazuje działanie synergistyczne z IMiD poprzez zmniejszenie stężenia cytokin, między innymi: IL-1 $\beta$, IL-2, IL-5, IL-6, IL-8 oraz czynnika martwicy nowotworów $\alpha$ (TNF $\alpha$, tumor necrosis factor $\alpha$ ). W badaniach in vivo wykazano również wpływ Cla na promowanie zjawiska autofagii i hamowanie angiogenezy w komórkach nowotworowych. Ponadto Cla zwiększa stężenie glikokortykosteroidów w surowicy. Należy jednak pamiętać, że Cla nie jest lekiem zarejestrowanym do leczenia chorych na PCM. Aktywność schematów zawierających Cla opisano w publikacjach przytoczonych powyżej, ale ich nie zweryfikowano w randomizowanych badaniach III fazy.

W prezentowanym przypadku klinicznym podczas kilkumiesięcznego leczenia według schematu Pd 2-krotnie wystąpiło zapalenie płuc, które skutkowało czasowym zaprzestaniem leczenia. Po dołączeniu Cla tolerancja terapii była dobra, nie obserwowano infekcji, co pozwoliło kontynuować chemioterapiię. Pacjentka zachorowała na PCM w wieku 36 lat, okres choroby wyniósł 26 lat, a schemat ClaPd był 9. linią leczenia. W okresie choroby obserwowano jej oporność zarówno po PI, jaki i IMiD. Przeżycie wolne od progresji podczas leczenia według schematu Pd wyniosło 7 miesięcy i było dłuższe niż mediana PFS w badaniu MM-003. Po stwierdzeniu progresji choroby, w celu zwiększenia skuteczności terapii, dołączono Cla (ClaPd) i wówczas chora uzyskała PR, a PFS zwiększyło się o kolejne 6 miesięcy.

$Z$ kolei dołączenie do POM i DEX leku alkilującego - Cy - zwiększało skuteczność terapii, ale również potęgowało efekt mielosupresyjny [31]. W badaniu klinicznym I/II fazy mediana PFS wynosiła 10,4 miesięcy (przy łącznej dawce Cy $700 \mathrm{mg} /$ cykl i zmniejszonej dawce POM do maksymalnie 2,5 mg/d. w dniach 1.-28.). Najczęstszymi hematologicznymi zdarzeniami niepożądanymi 3.-4. stopnia według WHO były neutropenia (42\%), małopłytkowość (11\%) i niedokrwistość (9\%). Ze względu na znaczną toksyczność terapii $9 \%$ chorych włączonych do badania nie ukończyło zaplanowanego leczenia, a ponadto u $9 \%$ wystąpiły infekcje o nasileniu od 3. do 5. stopnia według WHO (odnotowano po 1 incydencie sepsy i zapalenia pluc 5. stopnia). Ze względu na zdarzenia niepożądane 3.-4. stopnia według WHO $31 \%$ chorych wymagało zmniejszenia dawek leków.

Na uwagę zasługuje także inna terapia trójlekowa, w której poza POM i deksametazonem stosowano liposomalną doksorubicynę (PLD) [32]. Niestety, jest to terapia także obarczona dużą toksycznością, przy medianie PFS wynoszącej 5,3 miesiąca, a więc dłuższej o nieco ponad miesiąc od mediany PFS w badaniu MM-003, a krótszej o ponad 3 miesiące od mediany PFS w przypadku stosowania schematu ClaPd. Czterdziestu spośród 47 pacjentów (85\%) ze względu na działania niepożądane 3.-5. stopnia według WHO zaprzestało udziału w badaniu klinicznym.

Niezwykle obiecujące wydają się wyniki badań klinicznych, w których zastosowano CAR z POM i deksametazonem (CAR-POM-d) [33-35]. Całkowity odsetek odpowiedzi uzyskało $70 \%$ pacjentów, w tym 27\% - VGPR. Mediana PFS wynosiła 9,7 miesiąca, a prawdopodobieństwo rocznego OS obserwowano u $90 \%$ pacjentów. Wysoka skuteczność leczenia nie wiązała się ze wzrostem toksyczności. Najczęstszymi hematologicznymi zdarzeniami niepożądanymi 3.-4. stopnia według WHO były neutropenia (28\%), małopłytkowość (14\%), niedokrwistość (18\%) oraz gorączka neutropeniczna (4\%).

\section{Podsumowanie}

Mimo znaczącego rozwoju terapii u pacjentów z DRMM leczenie kolejnych nawrotów pozostaje ogromnym wyzwaniem. Obecnie dysponujemy nowymi lekami o różnych mechanizmach działania, tj. IMiD, IP, inhibitorami deacetylazy histonowej czy przeciwciałami monoklonalnymi. Pomalidomid stanowi jedną $z$ opcji terapeutycznych. Biorąc pod uwagę fakt, że lek ten jest zwykle stosowany u pacjentów po wielu liniach leczenia, wybór schematu trójlekowego powinien zależeć od sytuacji klinicznej pacjenta (potencjalna toksyczność leczenia, infekcje). Obiecującym schematem wydaje się połączenie POM $z$ deksametazonem i klarytromycyną, dzięki zwiększonej skuteczności leczenia przy akceptowalnej toksyczności.

\section{Piśmiennictwo}

1. Kumar S.K., Lee J.H., Lahuerta J.J. i wsp. Risk of progression and survival in multiple myeloma relapsing after therapy with IMiDs and bortezomib: a multicenter international myeloma working group study. Leukemia 2012; 26: 149-157.

2. Usmani S., Ahmadi T., Ng Y. i wsp. Analysis of real-world data on overall survival in multiple myeloma patients with $\geq 3$ prior lines therapy including proteasome inhibitor (PI) and an immunomodulatory drug (IMiD), or double refractory to a PI and an IMiD. Oncologist 2016; 21: 1355-1361.

3. Dimopoulos M.A., Terpos E., Chanan-Khan A. i wsp. Renal impairment in patients with multiple myeloma: a consensus statement on behalf of the International Myeloma Working Group. J. Clin. Oncol. 2010; 28: 4976-4984. 
4. Hoffmann M., Kasserra C., Reyes J. i wsp. Absorption, metabolism and excretion of pomalidomide in humans following oral administration. Cancer Chemother. Pharmacol. 2013; 71: 489-501.

5. Richardson P.G., Xie W., Mitsiades C. i wsp. Single-agent bortezomib in preoviously untreated multiple myeloma: efficacy, characterization of peripheral neuropathy, and molecular correlations with response and neuropathy. J. Clin. Oncol. 2009; 27: 3518-3525.

6. Tosi P., Zamagni E., Cellini C. i wsp. Neurological toxicity of long-term (>1yr) thalidomide therapy in patients with multiple myeloma. Eur. J. Hematol. 2005; 74: 212-216.

7. Meadows J.P., Mark T.M. Management of double-refractory multiple myeloma. Curr. Hematol. Malig. Rep. 2013; 8: 253-260.

8. Alsina M., Trudel S., Furman R.R. i wsp. A phase I single-agent study of twice weekly consecutive-day dosing of the proteasome inhibitor carfilzomib in patients with relapsed or refractory multiple myeloma or lymphoma. Clin. Cancer Res. 2012; 18 : 4830-4840.

9. Ludwig H., Masszi T., Petrucci M.T. i wsp. Carfilzomib (K) vs low-dose corticosteroids and optional cyclophosphamide (Cy) in patients (pts) with relapsed and refractory multiple myeloma (RRMM): results from a phase 3 study (FOCUS). Ann. Oncol. 2014; 25: 1-41.

10. Lonial S., Weiss B., Usmani S. i wsp. Daratumumab monotherapy in patients with treatment-refractory multiple myeloma (SIRIUS): an open-label, randomised, phase 2 trial. Lancet 2016; 387: 1551-1560.

11. Lee H.C., Shah J.J., Orlowski R. Novel approaches to treatment of "double-refractory" multiple myeloma. Am. Soc. Clin. Oncol. Edu. Book 2013: 302-306.

12. Wolf J.L., Siegel D., Goldschmidt H. i wsp. Phase II trial of the pan-deacetylase inhibitor panobinostat as a single agent in advanced relapse/refractory multiple myeloma. Leuk. Lymphoma 2012; 53: 1820-1823.

13. Nooka A.K., Kastritis E., Dimopoulos M.A. i wsp. Treatment options for relapsed and refractory multiple myeloma. Blood 2015; 125: 3085-3099.

14. Gerrie A.S., Mikhael J.R., Jiang H. i wsp. D(T)PACE as a salvage therapy for aggressive or refractory multiple myeloma. $\mathrm{Br}$. J. Haematol. 2013; 161: 802-810.

15. Ludwig H., Kasparu H., Leitgeb C. i wsp. Bendamustine-bortezomib-dexamethasone is an active and well-tollerated regimen in patients with relapsed or refractory multiple myeloma. Blood 2014; 123: 985-991.

16. Sellner L., Heiss C., Benner A. i wsp. Autologous retransplantation for patients with recurrent multiple myeloma. Cancer 2013; 119: 2438-2446.

17. Gahrton G., Svensson H., Cavo M. i wsp. Progress in allogeneic bone marrow and peripheral blood stem cell transplantation for multiple myeloma: a comparison between transplants performed 1983-93 and 1994-98 at European Group for Blood and Marrow Transplantation centres. Br. J. Haematol. 2001; 113: 209-216.

18. Dmoszyńska A., Walter-Croneck A., Usnarska-Zubkiewicz L. i wsp., Zalecenia Polskiej Grupy Szpiczakowej dotyczące rozpoznawania i leczenia szpiczaka plazmocytowego oraz innych dyskrazji plazmocytowych na rok 2015. Acta Haematol. Pol. 2015; 46: 159-211.

19. Escobet-Lozach L., Lin I-L., Jensen-Pergakes K. i wsp. Pomalidomide and lenalidomide induce p21 WAF-1 expressionin both lymphoma and multiple myeloma through a LSD1-mediated epigenetic mechanism. Cancer Res. 2009; 69: 7347-7356.
20. Verhelle D., Corral L.G., Wong K. i wsp. Lenalidomide and CC-4047 inhibit the proliferation of malignant b cells while expanding normal CD34+ progenitor cells. Cancer Res. 2007; 67: 746-755.

21. Li S., Pal R., Monaghan S.A. i wsp. IMiD immunomodulatory compounds block $\mathrm{C} / \mathrm{EBP}$ translation through eIF4E down-regulation resulting in inhibition of MM. Blood 2011; 117: 5157-5165.

22. Terpos E., Dimopoulos M.A., Sezer O. i wsp. The effect of novel antimyeloma agents on bone metabolism of patients with multiple myeloma. Leukemia 2007; 21: 1875-1884.

23. Anderson G., Gries M., Kurihara N. i wsp. Thalidomide derivative CC-4047 inhibits osteoclast formation by down-regulation of PU.1. Blood 2006; 107: 3098-3105.

24. Munemasa S., Sakai A., Kuroda Y. i wsp. Osteoprogenitor differentiation is not affected by immunomodulatory thalidomide analogs but is promoted by low bortezomib concentration, while both agents suppress osteoclast differentiation. Int. J. Oncol. 2008; 33: 129-136.

25. Miguel J.S., Weisel K., Moreau F. i wsp. Pomalidomide plus low-dose dexamethasone versus high-dose dexamethasone alone for patients with relapsed and refractory multiple myeloma (MM-003): a randomised, open-label, phase 3 trial. Lancet Oncol. 2013; 14: 1055-1066.

26. Mark T.M., Boyer A., Yadlapati S. i wsp. Clapd (clarithromycin, pomalidomide, dexamethasone) therapy in relapsed or refractory multiple myeloma overcomes negative prognostic impact of adverse cytogenetics and prior resistance to lenalidomide and bortezomib. Blood 2015; 126: 4232.

27. Mark T.M., Boyer A., Rossi A.C. i wsp. ClaPd (clarithromycin/ /[Biaxin $\left.{ }^{\circledR}\right]$, pomalidomide, dexamethasone). Therapy in relapsed or refractory multiple myeloma. Oral presented at: $54^{\text {th }}$ Annual Meeting of the American Society of Hematology (ASH) 2012, December 8-11. Atlanta, USA.

28. Morris T.C.M., Kettle P.J., Hull D.R. i wsp. Clarithromycin with low dose dexamethasone and thalidomide is effective therapy in relapsed/refractory myeloma. Br. J. Haematol. 2008; 143: 349-354.

29. Ghosh N., Tucker N., Zahurak M. i wsp. Clarithromycin overcomes resistance to lenalidomide and dexamethasone in multiple myeloma. Am. J. Hematol. 2014; 89: E116-E120.

30. Rossi A., Mark T., Jayabalan D. i wsp. BiRd (clarithromycin, lenalidomide, dexamethasone): an update on long-term lenalidomide therapy in previously untreated patient with multiple myeloma. Blood 2013; 121: 1982-1985.

31. Larocca A., Montefusco V., Bringhen S. i wsp. Pomalidomide, cyclophosphamide, and prednisone for relapsed/refractory multiple myeloma: a multicenter phase 1/2 open-label study. Blood 2013; 122: 2799-2806.

32. Berenson J., Stampleman L., Bessudo A. i wsp. A phase $1 / 2$ trial of pomalidomide, dexamethasone and pegylated liposomal doxorubicin for patients with relapsed/refractory multiple myeloma [abstract]. Proceedings of the $56^{\text {th }}$ Annual Meeting and Exposition of the American Society of Hematology (ASH) 2014, December 6-9. San Francisco, USA. Abstract \#4774.

33. Rosenbaum C.A., Kukreti V., Zonder J. i wsp. Phase $1 \mathrm{~b} / 2$ study of carfilzomib, pomalidomide, and dexamethasone (KPd) in patients with lenalidomide-exposed and/or- refractory but proteasome inhibitors-naïve or -sensitive multiple myeloma: a multiple myeloma research consortium multi-center study [abstract]. Proceedings of the $56^{\text {th }}$ Annual Meeting and Exposition of the American Society of Hematology (ASH) 2014, December 6-9. San Francisco, USA. Abstract \#2109. 


\section{Hematologia 2016, tom 7, nr 3}

34. Shah J.J., Standtmauer E.A., Abonour R. i wsp. A multi-center phase I/II trial of carfilzomib and pomalidomide with dexamethasone (Car-Pom-d) in patients with relapsed/refractory multiple myeloma [oral]. Oral presented at the $55^{\text {th }}$ Annual Meeting of the American Society of Hematology (ASH) 2013, December 7-10. New Orleans, USA.
35. Shah J.J., Standtmauer E.A., Abonour R. i wsp. A multi-center phase I/II trial of carfilzomib and pomalidomide with dexamethasone (Car-Pom-d) in patients with relapsed/refractory multiple myeloma [oral]. Oral presented at the $54^{\text {th }}$ Annual Meeting of the American Society of Hematology (ASH) 2012, December 8-11. Atlanta USA. 